\title{
Smart Parking System
}

\section{Madhumita Manish Kumar, Geetanjali B. Yatnalkar}

\begin{abstract}
Smart Parking System is based on Internet of Things technology and Android Application which enables the customer to view the available parking spaces and also book the parking space.Therefore, the project aimed at designing a system that will enable the customers to book the parking slot at their convenience.The data for functional, non-functional and system requirements were collected. This data was used to prepare the UML diagrams such as the Entity Relationship Diagram. This system was implemented using different IOT tools like IR sensors and also includes mobile application development for creating interfaces for booking parking slots.
\end{abstract}

Keywords: Arduino, Infrared sensors, Node Mcu.

\section{INTRODUCTION} Things (IOT) and Android application. The problem of traffic congestion is increasing day by day globally. Parking problem is a one of the biggest contributor to this issue and with the increasing luxurious vehicle sizes this situation is getting worse in the urban cities. Hunting for parking spaces is the most hectic work for every driver which has given rise to the requirement for proficient smart parking frameworks which will provide ease and consume less time in searching for parking spaces. Therefore, we have built IOT and android application based framework. To exhibit this idea, we use IR sensors for detecting the vehicles which arrives at the parking slot.We use NODE MCU8266 as wifi module and Arduino UNO as the main unit for receiving and sending data between the mobile application and IR sensors.This nodemcu8266 has an inbuilt Wi-Fi module for web connectivity and other services.We use Firebase as a cloud based server space for maintaining an online database and for handling the hardware signals coming to and from the MCU 8266 and the user application.The IR sensors identifies whether the parking slot is occupied or not, it uses the IR innovation to detect if a vehicle has arrived at the parking space.This framework reads the quantity of parking spaces accessible and refreshes information with the cloud server. Accordingly, this information is also updated in the mobile application and this allows customers to check free parking spaces available from anywhere at anytime.Thence, this system reduces the time- consuming parking issue and gives the client a productive IoT based parking system framework.

Manuscript received on August 19, 2021.

Revised Manuscript received on August 31, 2021.

Manuscript published on September 30, 2021.

* Correspondence Author

Madhumita Manish Kumar*, Department of Information Technology, Vivekanand Education Society College of Arts, Science and Commerce, Mumbai, India. E-mail: madhumitakumar2808@gmail.com

Geetanjali Yatnalkar, Department of Information Technology, Vivekanand Education Society College of Arts, Science and Commerce, Mumbai, India. E-mail: gyatnalkar92@gmail.com

(C) The Authors. Published by Blue Eyes Intelligence Engineering and Sciences Publication (BEIESP). This is an open access article under the CC BY-NC-ND license (http://creativecommons.org/licenses/by-nc-nd/4.0/)
Smart parking is based on the technology of Internet of

\section{SYSTEM DESIGN}

\section{A. NodeMcu V1.0(version 2)}

Fig.1. NodeMcu esp8266 is a LUA based IoT development board developed by ESP8266 WiFi..One of the unique feature of this is that it has an inbuilt support for WiFi connectivity.

For Programming NodeMCU I used the Node MCU, Arduino and USB cable. Connect the USB cable to the NodeMCU.

Install the Arduino IDE version 1.6 .9 ,once this is installed,use the USB cable to connect the Node MCU board with the computer. Open the Arduino IDE and select the correct board and Port Tools $>$ Boards $>$ NodeMCU1.0 (ESP12E Module)

Tools $>$ Port.

Now load the code onto the IDE and click on the 'upload' button given on the top bar. Once code is uploaded the builtin LED starts blinking. The code is successfully uploaded.

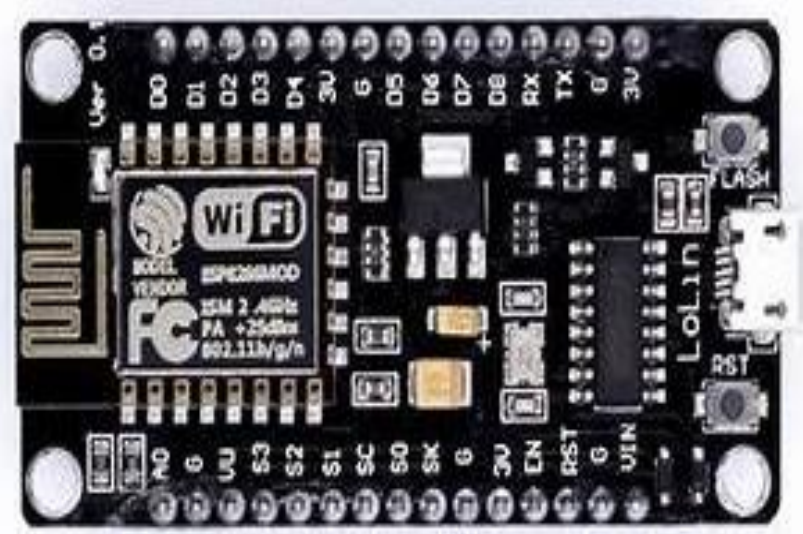

Fig. 1. Node MCU 8266

\section{B. Arduino UNO}

Fig. 2. Arduino Uno 8-bit ATmega328P microcontroller. Uno has 14 digital input/output pins.By using pinMode(), digitalRead() and digitalWrite() we can program the boards.Serial Pins $0(\mathrm{Rx})$ and 1 (Tx) are used to receive and transmit Transistor-Transistor Logic(TTL) serial data.

Arduino IDE (Integrated Development Environment)version 1.6.9 needs to be installed.Once this gets installed on the computer, use the USB cable to connect the board with computer.Open the arduino IDE and select the correct board and correct Port Tools $>$ Boards $>$ Arduino Uno Tools $>$ Port.

Now load the code and click on the 'upload' button given on the top bar. The code is uploaded successfully.

Published By:

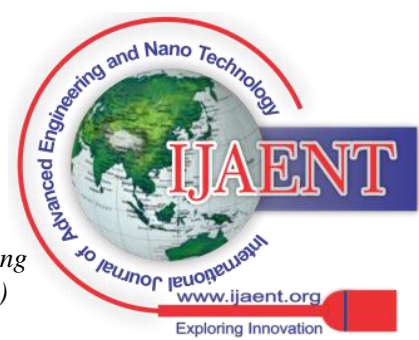




\section{Smart Parking System}

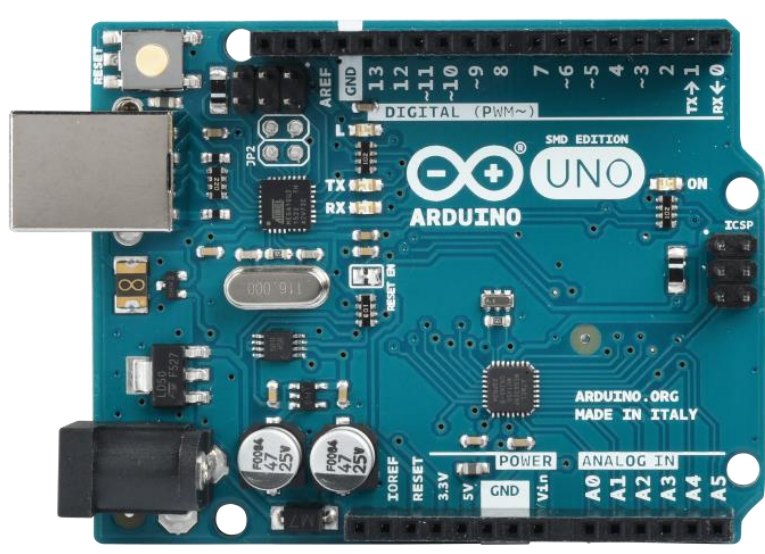

Fig. 2. Arduino UNO

\section{IR Sensors}

Fig. 3. IR sensor is a device which senses objects which are present in the surrounding by emitting infrared light.

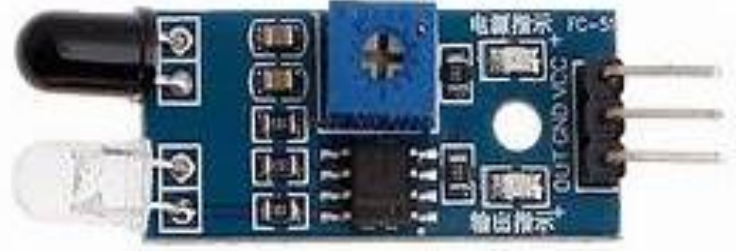

Fig. 3. IR Sensor

D. Connecting wire's

Fig.4. They provide a medium to an electrical current.

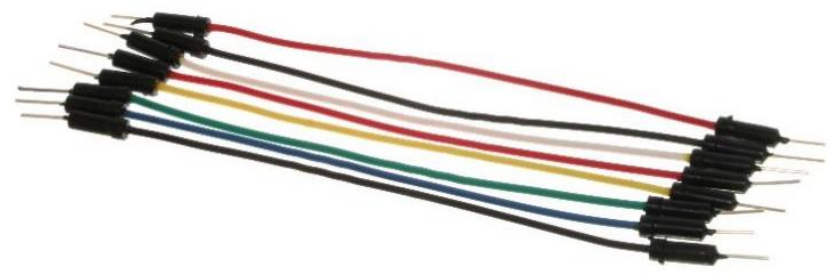

Fig. 4. Connecting Wires

\section{CIRCUIT DIAGRAM}

Fig. 5. Represents the Circuit Diagram of the system and Fig. 6. Represents the actual implemented circuit.

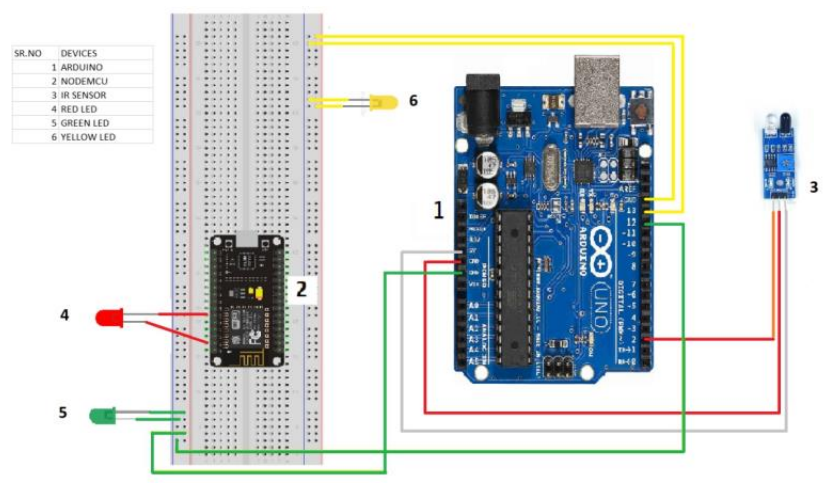

Fig. 5. Circuit Diagram

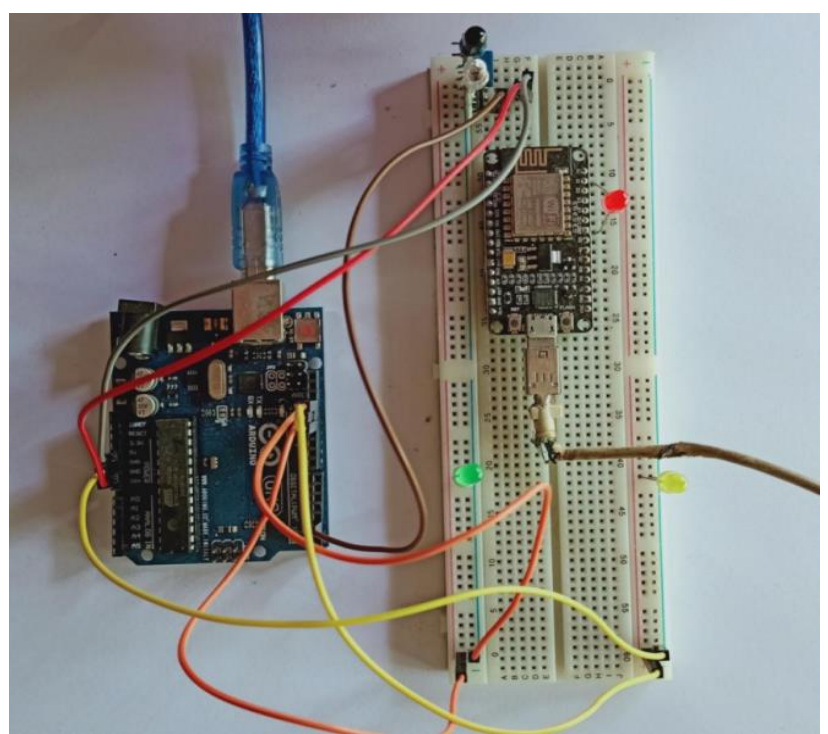

Fig. 6. Circuit

\section{SOFTWARE REQUIREMENTS}

1. Arduino IDE

2. Android Studio.

3. Firebase

\section{DATA DICTIONARY}

Table-I: Parking System Application

\begin{tabular}{|c|c|c|c|c|}
\hline $\begin{array}{c}\text { Serial } \\
\text { No. }\end{array}$ & $\begin{array}{l}\text { Column } \\
\text { Name }\end{array}$ & $\begin{array}{l}\text { Data } \\
\text { type }\end{array}$ & $\begin{array}{c}\text { Constrai } \\
\text { nts }\end{array}$ & $\begin{array}{c}\text { Description } \\
\mathrm{s}\end{array}$ \\
\hline 1 & slot_no & int & $\begin{array}{c}\text { Primary } \\
\text { key }\end{array}$ & $\begin{array}{l}\text { Primary } \\
\text { key for the } \\
\text { table }\end{array}$ \\
\hline 2 & $\begin{array}{c}\text { Car_plate } \\
\text { _no }\end{array}$ & varchar & Not null & $\begin{array}{c}\text { Indicate the } \\
\text { vehicle } \\
\text { number } \\
\text { plate }\end{array}$ \\
\hline 3 & TimeIn & int & Not null & $\begin{array}{c}\text { Time at } \\
\text { which the } \\
\text { car arrived } \\
\text { at parking } \\
\text { slot. }\end{array}$ \\
\hline 4 & TimeOut & int & Not null & $\begin{array}{l}\text { Time at } \\
\text { which the } \\
\text { car left } \\
\text { from } \\
\text { parking } \\
\text { slot. }\end{array}$ \\
\hline 5 & payment & float & Not null & $\begin{array}{l}\text { Indicate the } \\
\text { amount to } \\
\text { pay }\end{array}$ \\
\hline 6 & feedback & varchar & Not null & $\begin{array}{c}\text { User's } \\
\text { feedback }\end{array}$ \\
\hline \multicolumn{5}{|c|}{$\begin{array}{l}\text { Published By: } \\
\text { Blue Eyes Intelligence Engineering } \\
\text { and Sciences Publication (BEIESP) } \\
\text { (C) Copyright: All rights reserved. }\end{array}$} \\
\hline
\end{tabular}


Table-II: User Registration

\begin{tabular}{|c|c|c|c|c|}
\hline $\begin{array}{l}\text { Ser } \\
\text { ial } \\
\text { No. }\end{array}$ & $\begin{array}{l}\text { Column } \\
\text { Name }\end{array}$ & $\begin{array}{l}\text { Data } \\
\text { type }\end{array}$ & $\begin{array}{c}\text { Constraint } \\
\text { s }\end{array}$ & Descriptions \\
\hline 1 & Name & Char & Not null & $\begin{array}{c}\text { The name of } \\
\text { the user }\end{array}$ \\
\hline 2 & Email_id & $\begin{array}{c}\text { Nvarcha } \\
\text { r }\end{array}$ & $\begin{array}{c}\text { Primary } \\
\text { key }\end{array}$ & $\begin{array}{l}\text { Primary key } \\
\text { for the table }\end{array}$ \\
\hline 3 & Password & $\begin{array}{c}\text { Varchar( } \\
10)\end{array}$ & Not null & $\begin{array}{c}\text { Password of } \\
\text { user }\end{array}$ \\
\hline 4 & Phone_no & $\operatorname{Int}(10)$ & Not null & $\begin{array}{c}\text { Users } \\
\text { contact } \\
\text { number }\end{array}$ \\
\hline 5 & $\begin{array}{c}\text { Car_plate } \\
\text { no }\end{array}$ & $\begin{array}{c}\text { Varchar( } \\
10)\end{array}$ & Not null & $\begin{array}{l}\text { User's car } \\
\text { plate no }\end{array}$ \\
\hline
\end{tabular}

Table-III: User Login

\begin{tabular}{|c|c|c|c|c|}
\hline $\begin{array}{c}\text { Serial } \\
\text { No. }\end{array}$ & $\begin{array}{c}\text { Column } \\
\text { Name }\end{array}$ & $\begin{array}{c}\text { Data } \\
\text { type }\end{array}$ & Constraints & Descriptions \\
\hline 1 & Email_id & Char & $\begin{array}{c}\text { Primary } \\
\text { key }\end{array}$ & $\begin{array}{c}\text { User's } \\
\text { Email-id }\end{array}$ \\
\hline 2 & password & varchar & Not null & $\begin{array}{c}\text { Password of } \\
\text { the user }\end{array}$ \\
\hline
\end{tabular}

\section{UML DIAGRAMS}

\section{A. Entity Relationship Diagram}

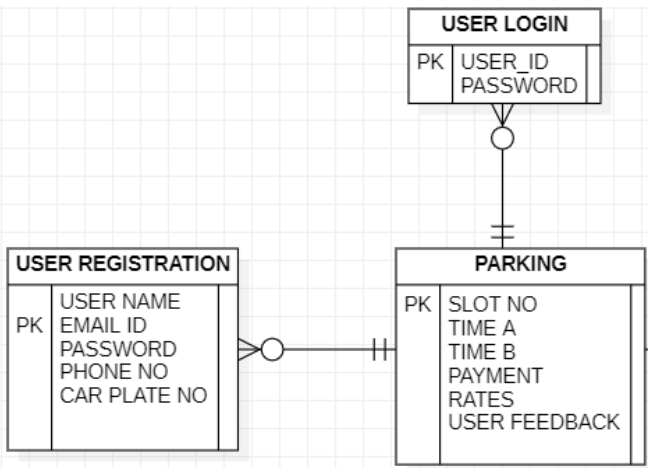

Fig. 7. ER Diagram

\section{B. State Transition Diagram}

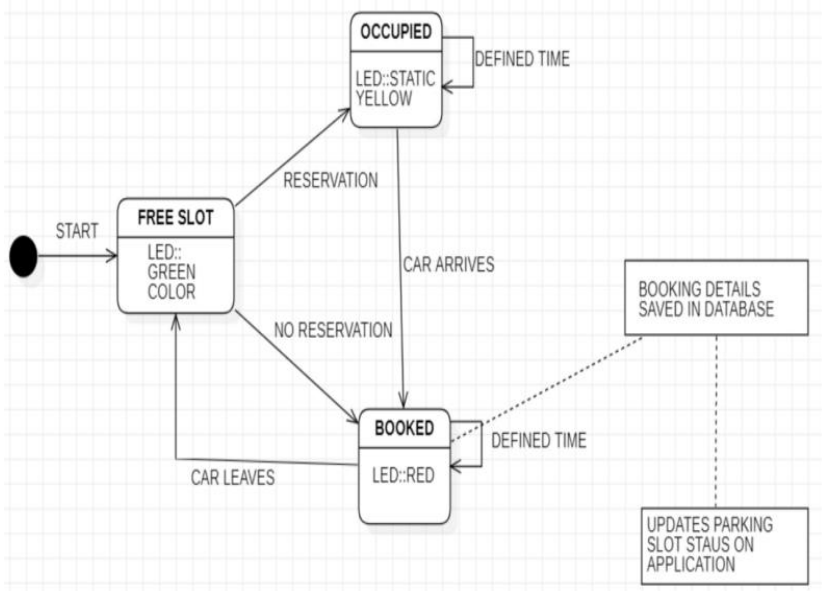

Fig. 8. State Transition Diagram

Retrieval Number: 100.1/ijaent.D0463084621

\section{Data Flow Diagram}

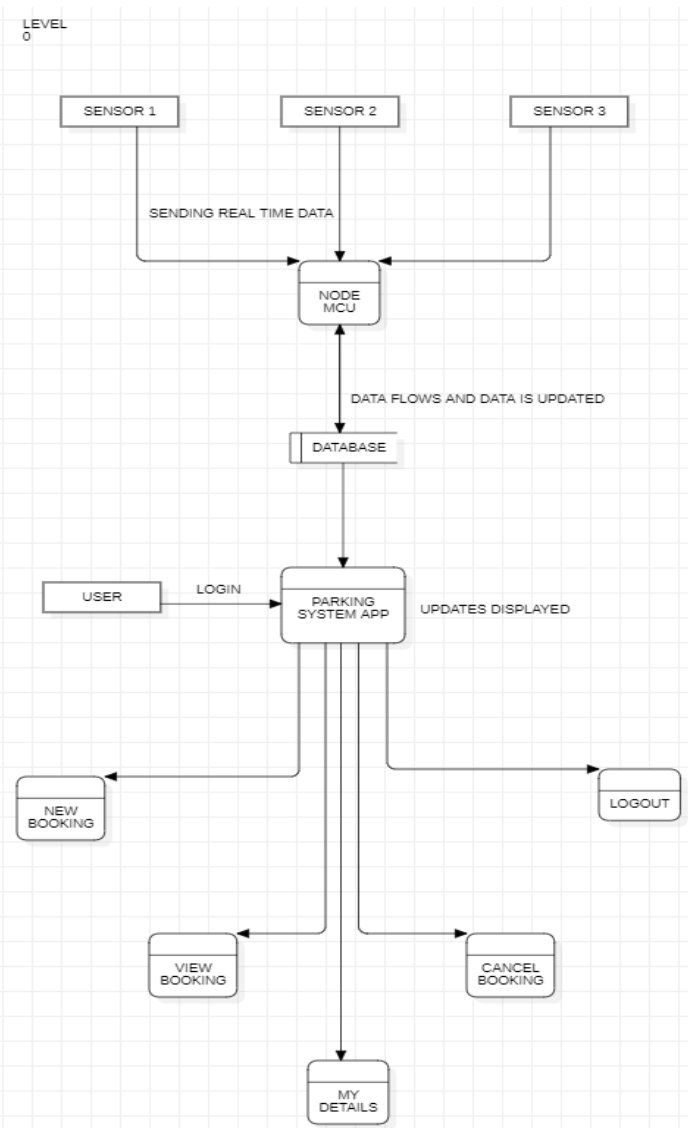

Fig. 9. DFD Diagram

VII. USER INTERFACE

User Interface (UI) is an important part of any development, because it is what the user sees first no matter how complicated the backend can be the UI needs to be appealing and easy to use for the user. Taking that into consideration I designed and implemented the interface of the mobile apps.

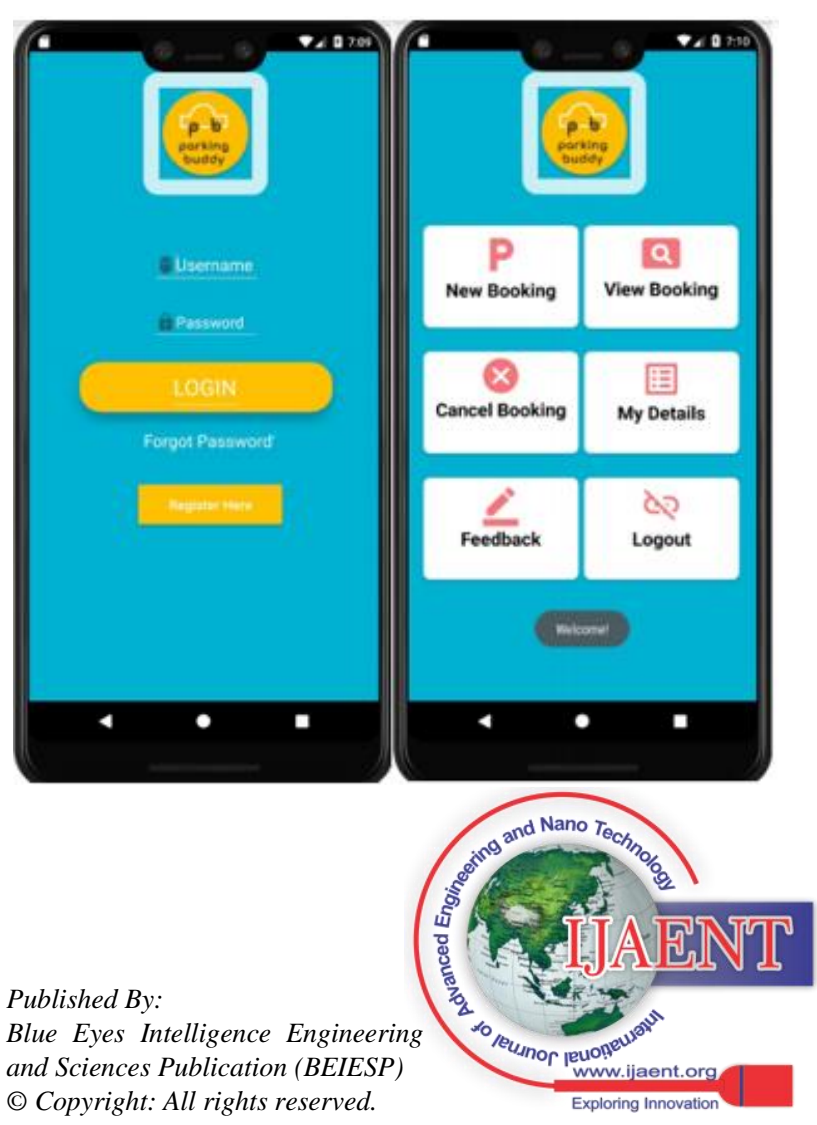




\section{Smart Parking System}
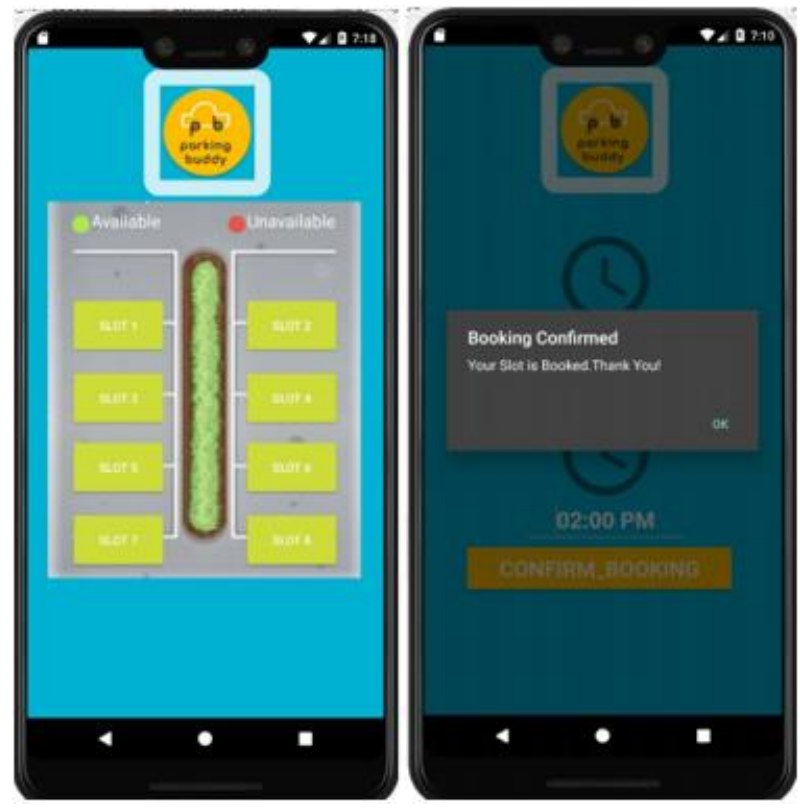

Fig. 10. Mobile Application Interface

\section{PARKING MODEL DESIGN}

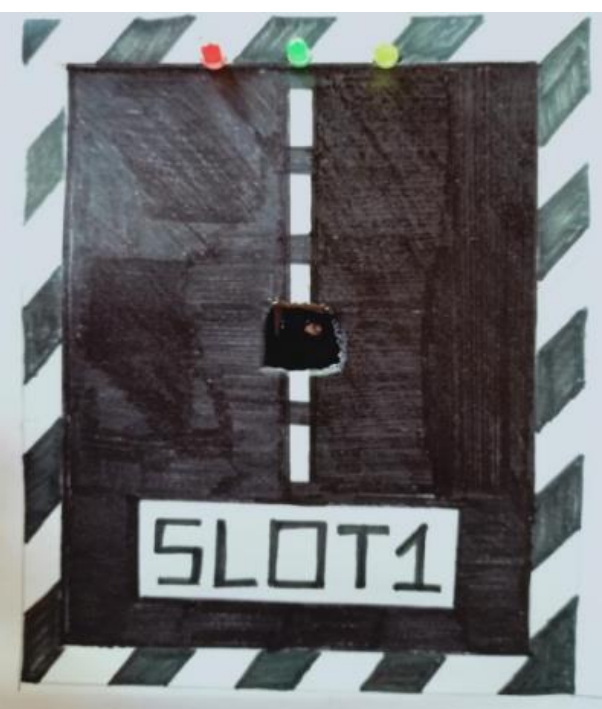

Fig. 11. Parking Slot Model

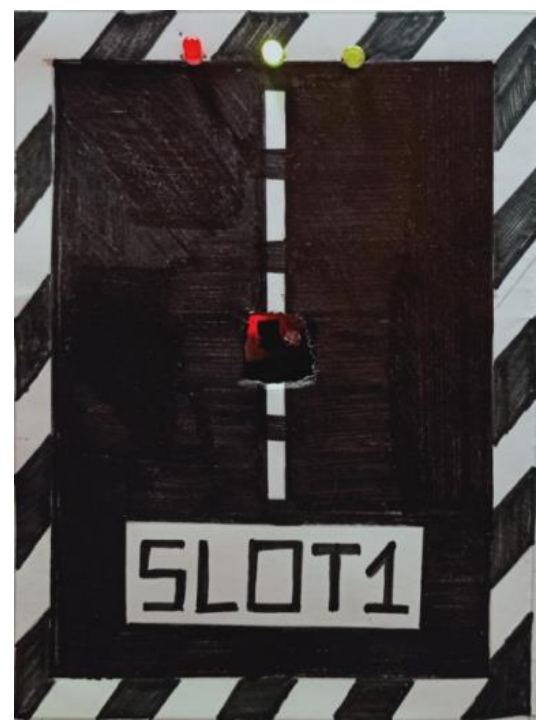

Fig. 12. Green LED glows when slot is empty

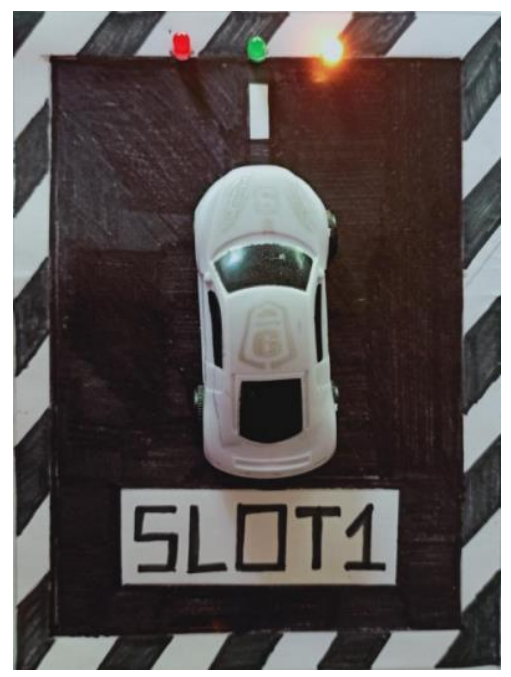

Fig. 13. Yellow LED glows when slot is occupied

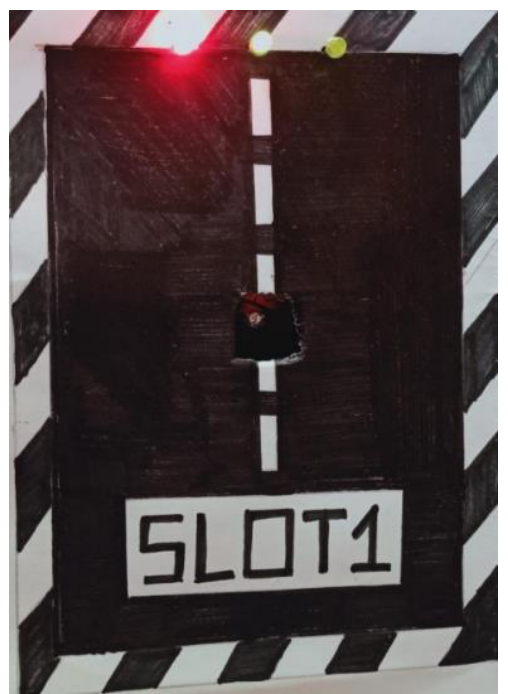

Fig. 14. Red LED glows when slot is booked by user through app

\section{TESTS AND RESULTS}

Table-I: Testing hardware

\begin{tabular}{ll|l} 
Test case & Test Data & Action \\
\hline 1 Testing IR Sensor & Car is placed near the IR sensor \\
\hline 2 Testing IR Sensor & Car is placed away from the IR sensor \\
\hline 3 Testing Red Led & User books the slot from mobile app \\
\hline 4 Testing Red Led & User cancels booking from mobile app
\end{tabular}

Expected Results

The Serial Monitor of Arduino IDE Displays output 1 and Yellow LED glows The Serial Monitor of Arduino IDE Displays output 0 and Green LED glows The Red Led turns ON

The Red Led turns OFF

Actual Result

Serial monitor displays 1 and Yellow Led glows Serial monitor displays 0 and Green Led glows The Red Led turned ON

The Red Led turned OFF

Table-II: Testing mobile application 


$$
\begin{array}{|c|l|l|}
\hline \text { Test case } & \text { Test Data } & \text { Action } \\
\hline 1 \text { User Registeration } & \text { Fill in the registration data and Clicks on Register button } \\
\hline 2 \text { User Login } & \text { Fill in Login data and click on login button } \\
\hline 3 \text { Forgot Password } & \text { Enter the registered email Id and click Submit Butoon } \\
\hline 3 \text { Booking a slot } & \text { Select time period and click Confirm Booking button } \\
\hline 4 \text { View Booking } & \text { Click on View Booking Button } \\
\hline 5 \text { Cancel Booking } & \text { Click on Confirm Cancelation Booking Button } \\
\hline 6 \text { View user Details } & \text { Click on my details Button } \\
\hline 7 \text { Feedback } & \text { Enter feedback and click on Submit Button } \\
\hline
\end{array}
$$

Expected Results

User data is registered Succesfully and data is stored to firebase

User should be authenticated and enter the Homepage

User should be sent password reset mail

Slot is booked and booking data should be sent to firebase

User Booking Details should be displayed

Booking is canceled and booking data should be deleted from firebase

User data should be displayed

Feedback shoud be sent to firebase

Actual Result

User data is registered Succesfully and data is stored to firebase User entered Homepage

User is sent a password reset mail

Slot is booked and booking data is sent to firebase

User Booking Details should be displayed

Booking is canceled and booking data is deleted from firebase

User data is displayed

Feedback is sent to firebase

The different tests on the different modules of the system were done for enhancements of the system . While testing the hardware, the focus was on time and accuracy. The sensors had no idea if what they are sensing is a car or not so there was a need to try different sensor positioning to achieve what is acceptable as an input without triggering any false sensing. Timing was not an issue because the sensors came with specification which were in accordance with what was set in the design stage. The Arduino and the Node MCU were a success too, data sent from the Arduino through the Node MCU to the server took an average of 3 to 3.6 seconds in a local connection. The data was received from IR sensors and application was stored and updated in the Firebase. The different modules of the application were also tested successfully.

\section{CONCLUSION}

The Smart Parking System worked convincingly by connecting the Arduino, NodeMcu, Firebase and mobile application together. All modules of this system were tested and are working successfully, thus proving its accuracy and compatibility. I also examined about the security concerns, since the real time data along with user details and vehicle details gets stored on the Firebase it can help to keep a track of everything. The driver can easily find a parking slot on the mobile app and book the slot without wasting his/her time in searching a parking. It also helps in preserving the environment, fuel and energy. Emissions are greatly brought down and reduced.. If the limiting factors such as better components are supported with proper funding, we can further develop it to a fully functional system that has commercial value. High convenience and flexibility along with mobile payment options are projected to increase growth in the commercial segment. Thus an efficient and effective Smart Parking System is successfully designed, implemented and tested.

\section{REFERENCES}

1. International Journal of Science and Research (IJSR) ISSN: 23197064 ResearchGate Impact Factor (2018): 0.28 | SJIF (2018): 7.426, Smart Security \& Home Automation Using Internet of Things (IoT)

2. https://www.researchgate.net/publication/324517934

3. IoT Smart Parking System Based on the Visual-Aided Smart Vehicle Presence Sensor: SPIN-V, Received : 21 February 2020; Accepted: 6 March 2020; Published: 8 March 2020

4. International Journal of Computer Applications (0975 - 8887) Volume 149 - No.9, September 2016, Smart Parking Application

5. Smart Parking: A Literature Review from the Technological Perspective, Received: 31 August 2019; Accepted: 11 October 2019; Published: 28 October 2019

6. https://www.researchgate.net/publication/332875468, Real Time Smart Car Parking System Using Internet of Things ,Article January 2019

7. https://www.researchgate.net/publication/320356747, Design and Implementation of Smart Car Parking System, Thesis · June 2016

8. https://en.wikipedia.org/wiki/Android_Studio

9. http://www.arduinobasics.blogspot.com/2012/07/arduino basics simple-arduino-serial.html

10. https://www.grandviewresearch.com/industry-analysis/smart parking-system-market January 15

11. https://www.youtube.com/watch?v=XfPhhKod2LI\&list=PLoHK50N FfvD_IOIORiOU4fCsYdxfe4N5L\&index $=1 \& \mathrm{t}=25 \mathrm{~s}$

12. https://www.youtube.com/watch?v=e1FVSpkw6q4\&list=PLoHK50 NFfvD_IOIORiOU4fCsYdxfe4N5L\&index=3

13. https://youtu.be/3RPJtL2rnXc?list=PLoHK50NFfvD_IOIORiOU4fC sYdxfe4N5L

14. https://www.youtube.com/watch?v=lgR0sk1f ZU\&list=PLoHK50N FfvD IOIORiOU4fCsYdxfe4N5L\&index=10

15. https://www.youtube.com/watch?v=y6P5ZNDIKmw\&list=PLoHK5 0NFfvD_IOIORiOU4fCsYdxfe4N5L\&index $=12$

16. https://www.youtube.com/watch?v=iDK6Fy2OkGo\&list=PLoHK50 NFfvD_IOIORiOU4fCsYdxfe4N5L\&index=19

17. https://www.youtube.com/watch?v=IEqsM7ERkn0\&list=PLoHK50 NFfvD_IOIORiOU4fCsYdxfe4N5L\&index $=21$

18. https://www.youtube.com/watch?v=DocKN8yX9qc\&list=PLoHK50 NFfvD_IOIORiOU4fCsYdxfe4N5L\&index $=24$

19. https://www.youtube.com/watch?v=09Y7HDkopHg\&list=PLoHK50 NFfvD_IOIORiOU4fCsYdxfe4N5L\&index $=25$

20. https://www.youtube.com/watch?v=lnidtzL71ZA\&list=PLoHK50NF fvD_IOIORiOU4fCsYdxfe4N5L\&index $=26$

21. https://www.youtube.com/watch?v=4G9p9BC9eYA\&list=PLoHK50 NFfvD_IOIORiOU4fCsYdxfe4N5L\&index $=27$

22. https://www.youtube.com/watch?v=rg2R COMqo\&list=PLoHK50NFfvD IOIORiOU4fCsYdxfe4N5L\&i $\underline{\text { ndex }=30}$

23. https://www.youtube.com/watch?v=iy6WexahCdY\&list=PLoHK50 NFfvD IOIORiOU4fCsYdxfe4N5L\&index $=31$

24. https://www.youtube.com/watch?v=dEWD60dYDgI\&list=PLoHK5 0NFfvD_IOIORiOU4fCsYdxfe4N5L\&index=53

25. https://www.youtube.com/watch?v=Vz3Y8s31gY\&list=PLoHK50NFfvD_IOIORiOU4fCsYdxfe4N5L\&in $\underline{\operatorname{dex}}=51$

\section{AUTHORS PROFILE}

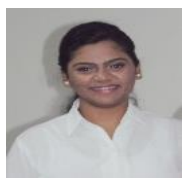

Madhumita Manish Kumar is an U.G student of Bachelor of Science in Information Technology from Vivekanand Education Society College of Arts, Science and Commerce.

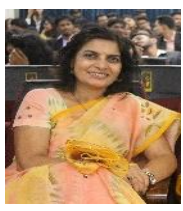

Geetanjali B. Yatnalkar has 21 years of teaching experience in the domain of Microprocessor Microcontroller and Electronics. She holds Bachelor degree in Industrial Electronics from Pune University and Master degree in Electronics from Mumbai University. She is affiliated to Vivekanand Education Society's college of Arts, Science and Commerce. Mumbai and other colleges as a visiting faculty.

Published By:

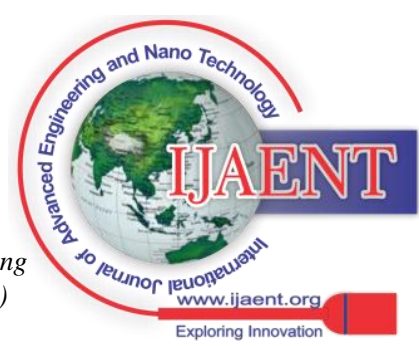

